\title{
Results of Recent High Temperature Co- Electrolysis Studies at the Idaho National Laboratory
}

\section{AlChE Annual Meeting}

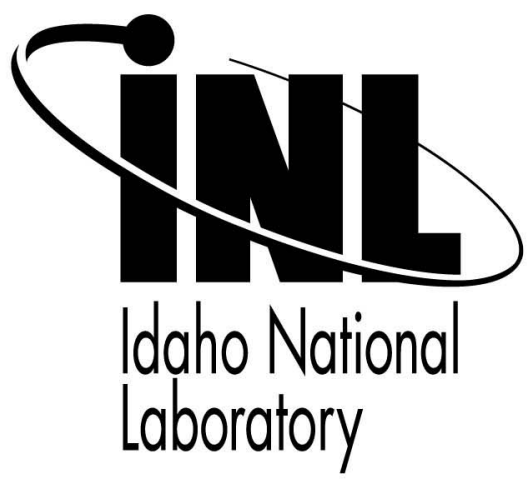

\author{
Carl Stoots \\ James O'Brien \\ Joseph Hartvigsen
}

November 2007

This is a preprint of a paper intended for publication in a journal or proceedings. Since changes may be made before publication, this preprint should not be cited or reproduced without permission of the author. This document was prepared as an account of work sponsored by an agency of the United States Government. Neither the United States Government nor any agency thereof, or any of their employees, makes any warranty, expressed or implied, or assumes any legal liability or responsibility for any third party's use, or the results of such use, of any information, apparatus, product or process disclosed in this report, or represents that its use by such third party would not infringe privately owned rights. The views expressed in this paper are not necessarily those of the United States Government or the sponsoring agency. 


\title{
RESULTS OF RECENT HIGH TEMPERATURE CO-ELECTROLYSIS STUDIES AT THE IDAHO NATIONAL LABORATORY
}

\author{
Carl Stoots, Idaho National Laboratory, Idaho Falls, ID, USA \\ James O'Brien, Idaho National Laboratory, Idaho Falls, ID, USA \\ Joseph Hartvigsen, Ceramatec Inc., Salt Lake City, UT, USA
}

\section{Introduction}

For the past several years, the Idaho National Laboratory (INL) and subcontractor Ceramatec, Inc. have been studying the feasibility of high temperature solid oxide electrolysis for large-scale, nuclear-powered hydrogen production. Parallel to this effort, the INL and Ceramatec have been researching high temperature coelectrolysis of steam $/ \mathrm{CO}_{2}$ mixtures to produce syngas:

$$
\mathrm{H}_{2} \mathrm{O}+\mathrm{CO}_{2} \longrightarrow \mathrm{H}_{2}+\mathrm{CO}+\mathrm{O}_{2}
$$

the raw material for synthetic fuels production. The INL and Ceramatec have been conducting experiments to characterize the electrochemical performance of coelectrolysis, as well as validate INLdeveloped computer models. An inline methanation reactor has also been tested to study direct methane production from coelectrolysis products. These activities include bench scale experimentation, modeling, and flow sheet analysis. When linked to nuclear power, high temperature coelectrolysis can provide a carbon neutral means of producing syngas while consuming $\mathrm{CO}_{2}$.

Coelectrolysis is significantly more complex than simple steam electrolysis. This is primarily due to the multiple reactions that occur: steam electrolysis, $\mathrm{CO}_{2}$ electrolysis, and the reverse shift reaction (RSR):

$$
\mathrm{CO}_{2}+\mathrm{H}_{2} \leftrightarrow \mathrm{CO}+\mathrm{H}_{2} \mathrm{O}
$$

Reaction kinetics govern the relative contributions of these three reactions. It is also important to note that the electrolysis reactions are not equilibrium reactions. The electrolyte separates the products from the reactants. However, the RSR is a kinetically fast, equilibrium reaction at high temperature in the presence of a Ni catalyst. Also, if the cell potential is high enough, $\mathrm{CO}$ can be further electrolyzed to elemental C:

$$
\mathrm{CO} \rightarrow \mathrm{C}+1 / 2 \mathrm{O}_{2}
$$

producing solid particulates that can then deposit on cell surfaces and reduce cell performance. Finally, there could be material compatibility issues related to corrosion and seal leakage.

It is also feasible to produce syngas by separately electrolyzing steam and $\mathrm{CO}_{2}$. There are, however, significant advantages to electrolyzing steam and $\mathrm{CO}_{2}$ simultaneously, the primary one of which is electrical efficiency. For a given solid oxide electrolysis cell, pure $\mathrm{CO}_{2}$ electrolysis will exhibit a higher area specific resistance (ASR) than steam electrolysis. This is due to the slower overall kinetics of $\mathrm{CO}_{2}$ electrolysis and the higher overpotentials required. In coelectrolysis, the reverse gas shift reaction is relied upon for most of the $\mathrm{CO}$ production and therefore the overall electrical requirement is less.

Some results of $\mathrm{CO}_{2} / \mathrm{H}_{2} \mathrm{O}$ electrolysis experiments performed to date using button cells and three different 10-cell planar solid oxide stacks are presented and discussed. These results include electrolysis performance at various temperatures, gas mixtures, and electrical settings. Product gas compositions, as measured via an online micro gas chromatograph (GC), are compared to predictions 


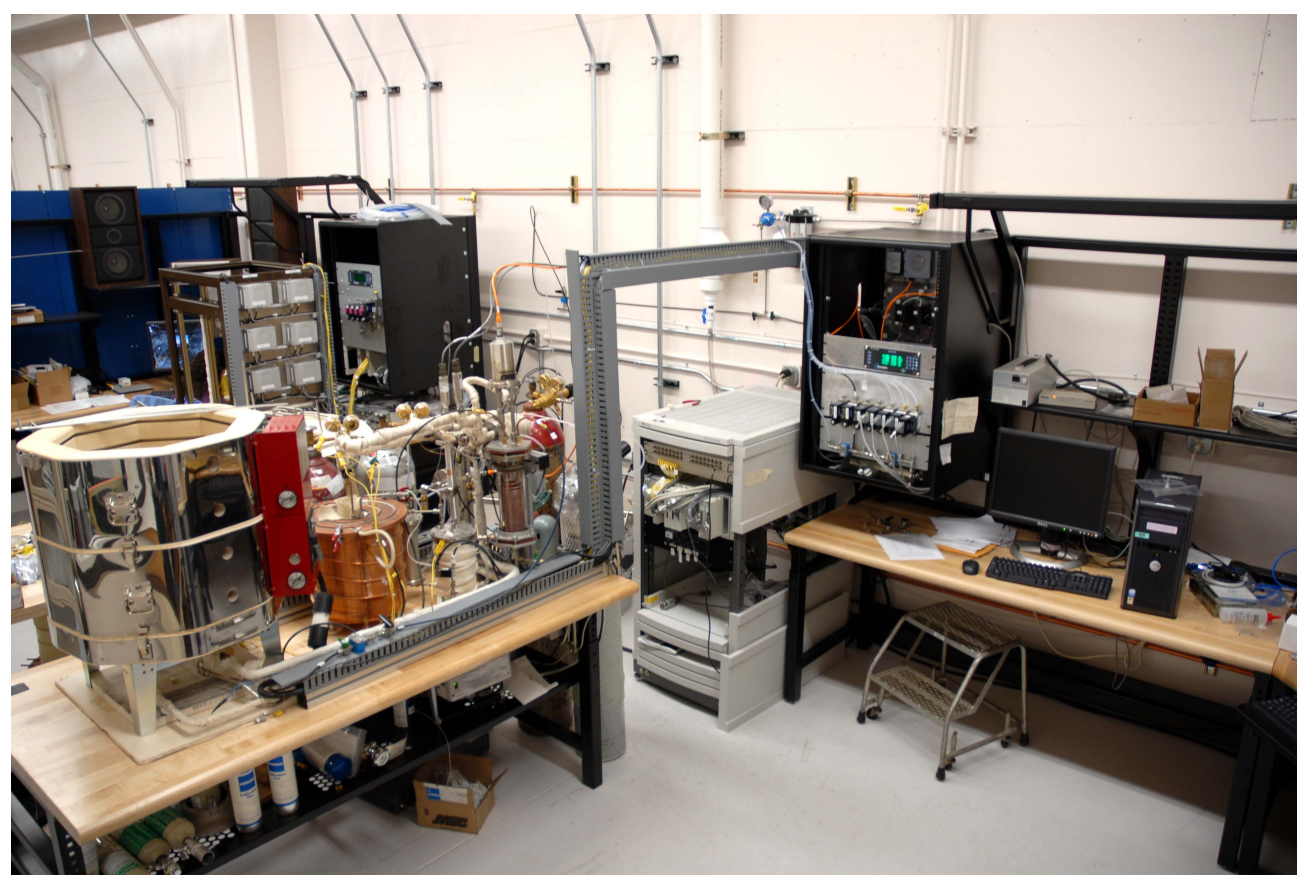

Fig. 1. Photograph of the INL high-temperature electrolysis laboratory.

obtained from an INL-developed chemical equilibrium coelectrolysis model (CECM). Better understanding of the feasibility of producing syngas using high temperature electrolysis may initiate the systematic investigation of nuclear-powered synfuel production as a bridge to the future hydrogen economy and ultimate independence from foreign energy resources.

\section{Experimental Test Facility}

A comprehensive discussion of the INL high temperature solid oxide electrolysis test facility is presented elsewhere $[1,2,3]$. This same facility is used for button cell testing as well as stack testing. A photograph of the test hardware is in Fig. 1. Primary components include gas supply cylinders, mass-flow controllers, a humidifier, dewpoint measurement stations, carbon dioxide concentration measurement stations, microchannel gas chromatograph, temperature and pressure measurement, high temperature furnaces, and a solid oxide electrolysis cell/stack.

For single-cell testing, an electrolysis button cell is bonded to the bottom of a zirconia tube, as shown in Fig. 2. During testing, the tube is suspended in the smaller furnace. The cell is an electrolyte-supported single button cell with a scandia-stabilized zirconia electrolyte, about $150 \mu \mathrm{m}$ thick. The outside electrode, which acts as the cathode in fuel cell mode and the anode in electrolysis mode, is a doped manganite. The inside electrode (electrolysis cathode) material is a nickel cermet. Both button-cell electrodes incorporate a platinum wire mesh for current distribution. The button

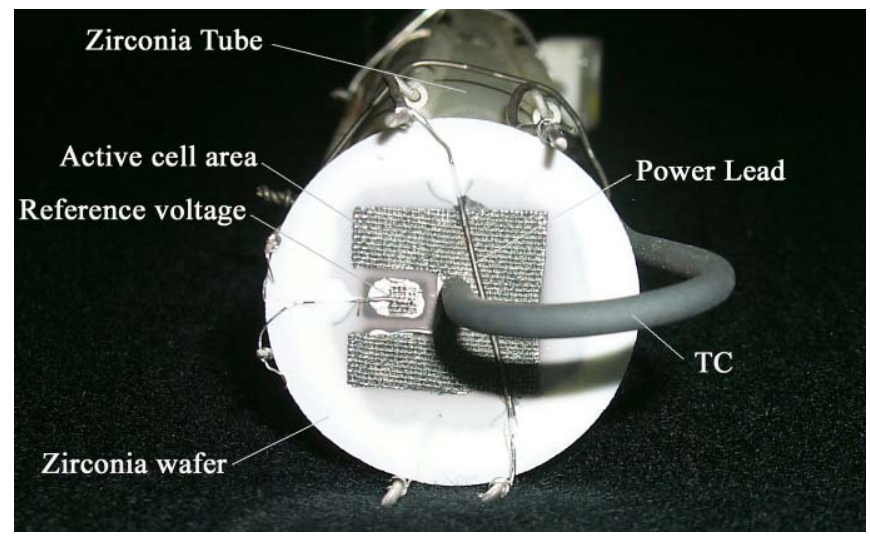

Fig. 2. Detail of button cell. 


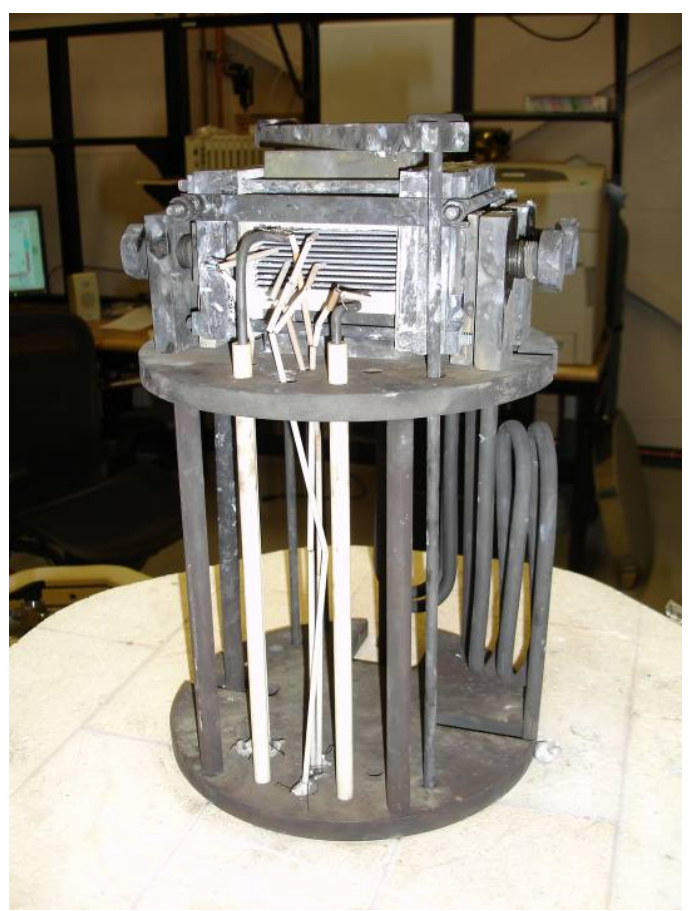

Fig. 3. 10-cell stack mounted on test fixture on furnace base, ready to test. cell includes both an active cell area $\left(2.5 \mathrm{~cm}^{2}\right.$ for the cell shown) and a reference cell area. A type-K stainlesssteel sheathed thermocouple, is mounted on the manifold tube and bent around in front of the button cell in order to allow for continuous monitoring of the button-cell temperature.

For stack testing, the inlet gas mixture is directed to the larger high temperature furnace (Skutt Model KS818-3), capable of producing temperatures up to $1250^{\circ} \mathrm{C}$, which heats and maintains the electrolyzer at the appropriate test temperature via computer-based feedback control. The furnace also preheats the inlet gas mixture and the air sweep gas. A photograph of the stack, mounted on its inconel test fixture and resting on the furnace base, is shown in Fig. 3. The button cells and stacks were fabricated by Ceramatec, Inc., of Salt Lake City, UT. The stacks have a per-cell active area of 64 $\mathrm{cm}^{2}$, for a total active area of $640 \mathrm{~cm}^{2}$ each.

\section{Single-Cell Experimental Results}

To understand the impact of the electrolysis reactions and the RSR discussed above, and to assist with interpretation of experimentally measured data, a CECM was developed. This model also served to help determine the necessary inlet conditions for the range of experiments that were conducted. A discussion of the INL-developed model can be found in $[4,5]$.

Coelectrolysis performance was characterized through a series of stepwise DC potential sweeps. Results of three sweeps are presented in Fig. 4. The furnace temperature for all three sweeps was $800^{\circ} \mathrm{C}$. Inlet gas flow rates and inlet dewpoint values for each of these three sweeps are provided in Table 1. The corresponding inlet volume flow rate of steam is also provided in the table. Sweep 1 had the highest steam flow rate; sweep 3 had the lowest. Note that the flow rates used for these test were quite small. Low flow rates were required in order to achieve reasonable steam and $\mathrm{CO}_{2}$ utilization values with low values of total cell current. The single cell, with an active area of $2.5 \mathrm{~cm}^{2}$, could only support a maximum total current of about $0.75 \mathrm{~A}$.

Fig. 4 plots the mole percent of $\mathrm{H}_{2}, \mathrm{CO}$, and $\mathrm{CO}_{2}$ as a function of cell current on a dry basis. The data symbols represent measurements obtained from the gas chromatograph. The lines represent predictions based on our CECM. Two lines are shown for each case. The dashed lines represent CECM predictions based on an effective equilibrium temperature of $700^{\circ} \mathrm{C}$. The dotted lines represent CECM predictions based on an effective equilibrium temperature of $650^{\circ} \mathrm{C}$. The RSR equilibrium constant is a function of temperature. Since product gases cool to room temperature before
Table 1. Inlet conditions for DC potential sweeps.

\begin{tabular}{|l|c|c|c|}
\hline & $\begin{array}{c}\text { Sweep } \\
1\end{array}$ & $\begin{array}{c}\text { Sweep } \\
2\end{array}$ & $\begin{array}{c}\text { Sweep } \\
3\end{array}$ \\
\hline$Q_{N 2}(\mathrm{sccm})$ & 35 & 50 & 40 \\
\hline$Q_{H 2}(\mathrm{sccm})$ & 4 & 3 & 8 \\
\hline$Q_{C O 2}(\mathrm{sccm})$ & 8 & 6 & 8 \\
\hline$T_{d p, i}\left({ }^{\circ} \mathrm{C}\right)$ & 55.1 & 44.6 & 30.1 \\
\hline$Q_{H 2 O}(\mathrm{sccm})$ & 10.67 & 7.27 & 2.93 \\
\hline$T_{f}\left({ }^{\circ} \mathrm{C}\right)$ & 800 & 800 & 800 \\
\hline
\end{tabular}


analysis in the micro GC, it was not certain what value to use for an "apparent" equilibrium temperature for the products. Therefore, the chemical equilibrium coelectrolysis model was run for several different equilibrium temperatures.

During coelectrolysis, the mole fractions of $\mathrm{CO}_{2}$ and steam (not shown in Fig. 4) decrease with current, while the mole fractions of $\mathrm{H}_{2}$ and $\mathrm{CO}$ increase. For the conditions chosen for these tests, the ratio of $\mathrm{H}_{2}$ to $\mathrm{CO}$ is close to the desired 2-to-1 value for syngas production. Measured compositions of $\mathrm{CO}_{2}$ and $\mathrm{CO}$ agree best with predictions based on an effective equilibrium temperature of $700^{\circ} \mathrm{C}$. Measured compositions of $\mathrm{H}_{2}$ agree best with predictions based on an effective equilibrium temperature of $650^{\circ} \mathrm{C}$.

\section{Discussion of 10-Cell Stack Test Results}

Table 2 lists the coelectrolysis stack testing conducted. Cell area-specific resistance, ASR, quantifies the loss mechanisms associated with cell operation, including ohmic resistances, contact resistances, and ionic resistances, activation and concentration overpotentials. The ASR value is dependent on the type of electrolysis being conducted, with pure $\mathrm{CO}_{2}$ electrolysis exhibiting a significantly higher ASR than pure steam electrolysis [4,5]. However, in coelectrolysis the RSR is relied upon for most $\mathrm{CO}_{2}$-to-CO conversion, and steam electrolysis is the primary electrolytic reaction. Therefore, there is little change in ASR from steam electrolysis to coelectrolysis. To demonstrate this, polarization curves were generated for stack \#3 for steam electrolysis, $\mathrm{H}_{2} \mathrm{O} / \mathrm{CO}_{2}$ coelectrolysis, and $\mathrm{CO}_{2}$ electrolysis. Once the stack was at the operating temperature of $800^{\circ} \mathrm{C}$, a steam electrolysis polarization curve was generated by performing a voltage sweep for the conditions labeled "Test \#20" in Table 2. This same voltage sweep was repeated for

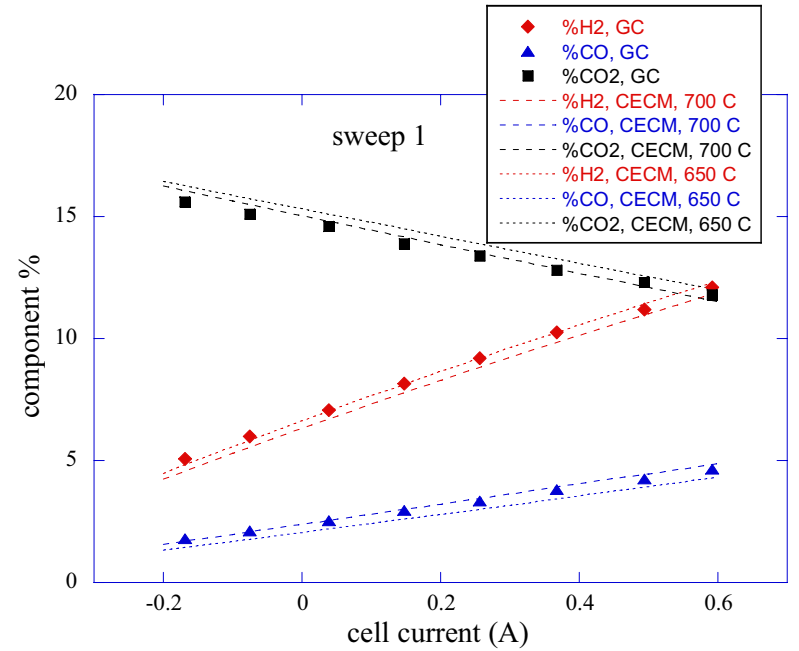

(a)

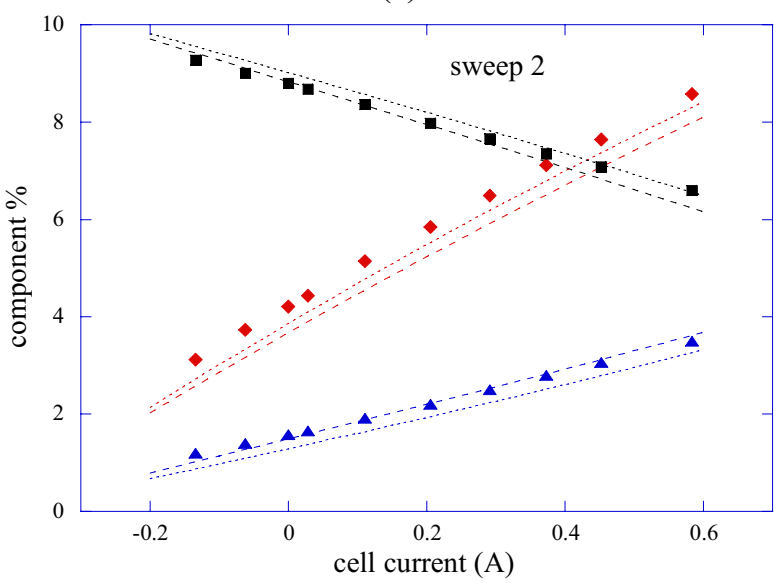

(b)

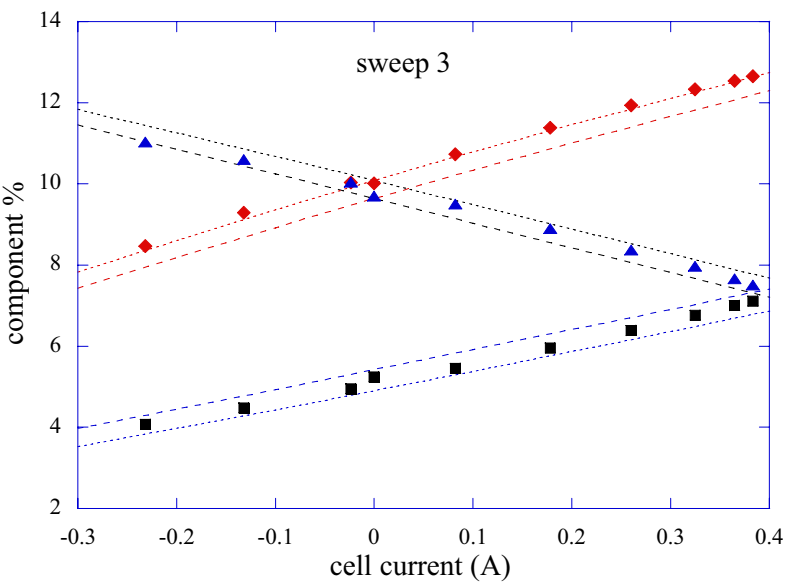

(c)

Fig. 4. Measured outlet gas compositions, with comparisons to predictions from the chemical equilibrium coelectrolysis model, sweeps $1-3$. 
Table 2. Summary of stack testing conditions.

\begin{tabular}{|c|c|c|c|c|c|c|c|c|c|c|c|c|}
\hline \multirow{2}{*}{$\begin{array}{c}\text { Test } \\
\#\end{array}$} & \multirow{2}{*}{$\begin{array}{c}\text { Stack } \\
\#\end{array}$} & \multirow{2}{*}{$\begin{array}{c}\text { Sweep } \\
\text { Type }\end{array}$} & \multirow{2}{*}{$\begin{array}{c}\text { Stack } \\
\text { Age }\end{array}$} & \multirow{2}{*}{$\begin{array}{l}\mathrm{T}_{\text {furnace }} \\
\text { (C) }\end{array}$} & \multicolumn{3}{|c|}{ Flow Rates } & \multirow{2}{*}{$\begin{array}{l}\text { Inlet } \\
\text { Dew } \\
\text { Point } \\
\text { (C) }\end{array}$} & \multicolumn{4}{|c|}{ Molar Composition } \\
\hline & & & & & $\begin{array}{c}\mathrm{H}_{2} \\
\text { (sccm) }\end{array}$ & $\begin{array}{c}\mathrm{CO}_{2} \\
(\mathrm{sccm})\end{array}$ & $\begin{array}{c}\mathrm{N}_{2} \\
(\mathrm{sccm})\end{array}$ & & $\begin{array}{c}\mathrm{H}_{2} \\
(\mathrm{~mol} \mathrm{\% )})\end{array}$ & $\begin{array}{c}\mathrm{CO}_{2} \\
(\mathrm{~mol} \%)\end{array}$ & $\begin{array}{c}\mathrm{N}_{2} \\
(\mathrm{~mol} \%)\end{array}$ & $\begin{array}{c}\mathrm{H}_{2} \mathrm{O} \\
(\mathrm{mol} \%)\end{array}$ \\
\hline 0 & 1 & Fast & Fresh & 800 & 497 & 0 & 3010 & 51.5 & 12.0 & 0 & 72.6 & 15.4 \\
\hline 1 & 1 & Fast & Fresh & 800 & 497 & 605 & 3010 & 51.5 & 10.2 & 12.4 & 61.9 & 15.5 \\
\hline 2 & 1 & Slow & Fresh & 800 & 497 & 605 & 3010 & 51.5 & 10.2 & 12.4 & 61.9 & 15.5 \\
\hline 3 & 1 & Slow & Fresh & 800 & 497 & 505 & 2510 & 45.5 & 12.6 & 12.7 & 63.3 & 11.4 \\
\hline 4 & 1 & Slow & Fresh & 800 & 497 & 705 & 1010 & 66.0 & 15.6 & 22.2 & 31.8 & 30.4 \\
\hline 5 & 1 & Slow & Fresh & 800 & 497 & 756 & 3010 & 74.0 & 6.7 & 10.1 & 40.2 & 43.0 \\
\hline 6 & 1 & Slow & Fresh & 828 & 497 & 605 & 3011 & 51.5 & 10.2 & 12.4 & 61.9 & 15.5 \\
\hline 7 & 1 & Slow & Fresh & 828 & 497 & 756 & 3513 & 65.3 & 7.3 & 11.2 & 52.0 & 29.5 \\
\hline 8 & 2 & Fast & Fresh & 800 & 450 & 0 & 1413 & 75.3 & 13.2 & 0 & 41.4 & 45.4 \\
\hline 9 & 2 & Fast & Fresh & 800 & 449 & 753 & 1414 & 59.8 & 13.2 & 22.2 & 41.6 & 23.0 \\
\hline 10 & 2 & Fast & Fresh & 800 & 334 & 564 & 1064 & 59.7 & 13.1 & 22.2 & 41.8 & 22.9 \\
\hline 11 & 2 & Fast & Fresh & 800 & 213 & 378 & 710 & 60.7 & 12.4 & 22.1 & 41.5 & 24.0 \\
\hline 12 & 2 & Slow & $1 \mathrm{Week}$ & 800 & 449 & 753 & 1414 & 59.8 & 13.2 & 22.2 & 41.6 & 23.0 \\
\hline 13 & 2 & Slow & 1 Week & 800 & 334 & 564 & 1064 & 59.7 & 13.1 & 22.2 & 41.8 & 22.9 \\
\hline 14 & 2 & Slow & 1 Week & 800 & 213 & 378 & 710 & 60.7 & 12.4 & 22.1 & 41.5 & 24.0 \\
\hline 15 & 2 & Slow & 1 Week & 830 & 497 & 756 & 3513 & 65.3 & 7.4 & 11.2 & 52.0 & 29.4 \\
\hline 16 & 2 & Slow & 2 Weeks & 800 & 450 & 752 & 1410 & 60.3 & 13.2 & 22.0 & 41.3 & 23.5 \\
\hline 17 & 2 & Slow & 2 Weeks & 800 & 334 & 564 & 1064 & 60.2 & 13.0 & 22.0 & 41.5 & 23.5 \\
\hline 18 & 2 & Slow & 2 Weeks & 800 & 213 & 378 & 710 & 60.7 & 12.4 & 22.1 & 41.5 & 24.0 \\
\hline 19 & 2 & Slow & 2 Weeks & 830 & 497 & 756 & 3513 & 65.3 & 7.4 & 11.2 & 52.0 & 29.4 \\
\hline 20 & 3 & Fast & Fresh & 800 & 996 & 0 & 1009 & 80 & 22.5 & 0 & 22.7 & 54.8 \\
\hline 21 & 3 & Fast & Fresh & 800 & 996 & 1003 & 0.0 & 80 & 22.5 & 22.6 & 0 & 54.9 \\
\hline 22 & 3 & Fast & Fresh & 800 & 0 & 1500 & 0 & 0 & 0 & 100.0 & 0 & 0 \\
\hline
\end{tabular}

the coelectrolysis conditions "Test \#21" and for the $\mathrm{CO}_{2}$ electrolysis conditions "Test \#22". These results are shown in Fig. 5.

There was almost no change in apparent ASR for coelectrolysis versus steam electrolysis. However, the ASR for $\mathrm{CO}_{2}$ electrolysis was significantly higher, reinforcing the hypothesis that steam electrolysis is the principal electrolysis reaction and that the RSR is mostly responsible for $\mathrm{CO}$ production.

Tests 1 through 6 comprised very slow voltage sweeps where for each power supply voltage setting the stack was allowed to reach thermal and chemical equilibrium. Thermal equilibrium was determined by watching the response of the stack internal thermocouples. Chemical equilibrium was recognized when the downstream dew point reading reached steady state. These two conditions were usually met after approximately 10 minutes at each setting.

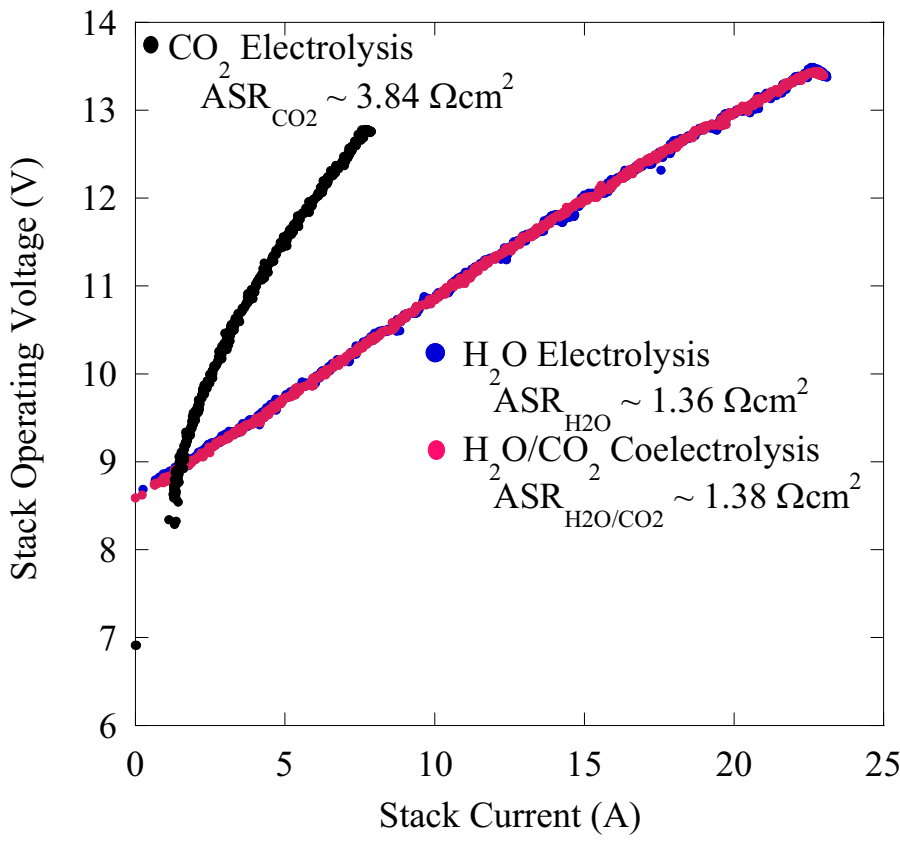

Fig. 5. Polarization curves for $\mathrm{H}_{2} \mathrm{O}$ electrolysis, $\mathrm{H}_{2} \mathrm{O} / \mathrm{CO}_{2}$ coelectrolysis versus $\mathrm{CO}_{2}$ coelectrolysis, with mean ASR values. 
Fig. 6 presents internal stack temperature depression (the difference between the temperature measured during the sweep and the temperature at open cell conditions) as a function of stack operating voltage for the electrolysis conditions listed in Table 2. When a solid oxide cell is operated as a fuel cell, the exothermic heat of reaction as well as ohmic heating tends to increase the cell temperature and excess air is typically required for cooling. Steam electrolysis, $\mathrm{CO}_{2}$ electrolysis, and the RSR, however, are endothermic reactions which tend to reduce the cell temperature in proportion to the electrolysis current. Ohmic heating is proportional to the square of the electrolysis current. These two effects balance each other at the thermal neutral voltage. At operating voltages below thermal neutral, the endothermic heat of reaction dominates and the cell temperature is lower than

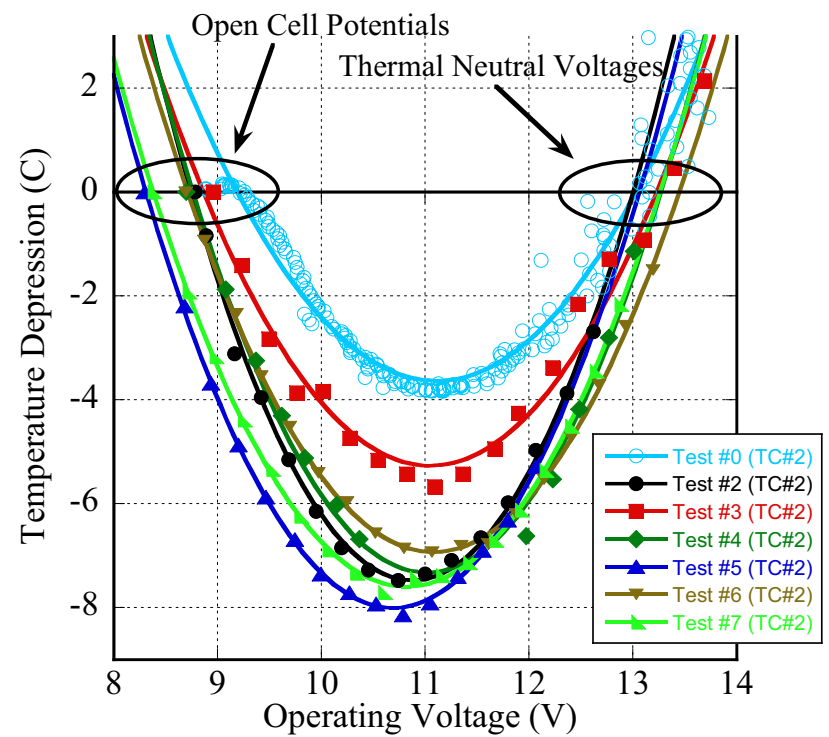

Fig 6. Internal stack temperature (thermocouple \#2) for various test conditions.

that at open cell. At operating voltages above thermal neutral, ohmic heating dominates and the cell temperature will exceed that at open cell. For pure steam electrolysis, the thermal neutral voltage is a weak function of temperature only and is equal to $1.287 \mathrm{~V}$ at $800^{\circ} \mathrm{C}$ and $1.288 \mathrm{~V}$ at $830^{\circ} \mathrm{C}$. For coelectrolysis the thermal neutral voltage is also a function of gas composition.

Figs. 7-12 present the steady state outlet compositions of steam, $\mathrm{CO}_{2}$, hydrogen, and $\mathrm{CO}$ as a function of electrolysis current on a dry basis for tests 1-6. Lines represent various model predictions and symbols represent experimental measurements. An in-line gas chromatograph was used to measure outlet compositions from the stack. The chemical equilibrium coelectrolysis model was run for several different equilibrium temperatures ranging from $650^{\circ} \mathrm{C}$ to $800^{\circ} \mathrm{C}$ (Fig. 7). It was found that setting the chemical equilibrium coelectrolysis model equilibrium temperature equal to the furnace temperature produced the best comparisons, indicating that the products are kinetically frozen after they leave the hot zone. This is different than the button cell case and is due to the much higher gas flow rates and correspondingly shorter residence times, lack of any significant catalyst surface, and the rapid cool-down. Predicted compositions were therefore evaluated at the electrolyzer temperature for all subsequent evaluations (Fig. 8-12).

Figs. 7-12 demonstrate that even at zero current there was a drop in $\mathrm{CO}_{2}$ and $\mathrm{H}_{2}$ mole fractions from the cold inlet values, with $\mathrm{CO}$ produced. This is solely due to the RSR. As the electrolysis current was increased, the yield of syngas increased linearly while the concentration of $\mathrm{CO}_{2}\left(\right.$ and $\mathrm{H}_{2} \mathrm{O}$, not shown in the figures) decreased. These figures also show overall good agreement between experimental GC data and results from the CECM for the range of testing performed in this study. Finally, in the case of Test \#6, at the maximum current studied the product $\mathrm{H}_{2}$ concentration was doubled and product $\mathrm{CO}_{2}$ concentration was reduced to half that of the process inlet mixture. Coelectrolysis significantly increases the yield of syngas over the reverse water gas shift reaction equilibrium composition. 


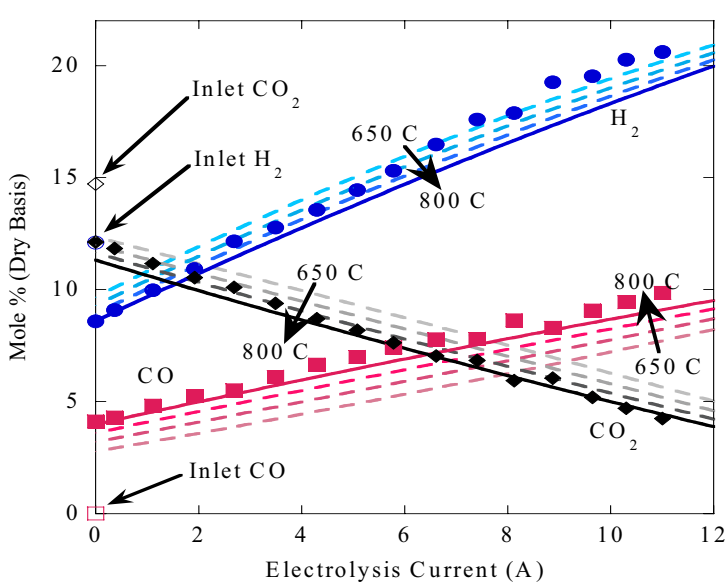

Fig. 7. Effect of varying chemical equilibrium coelectrolysis model equilibrium temperature with comparison to Test 1 experimental data.

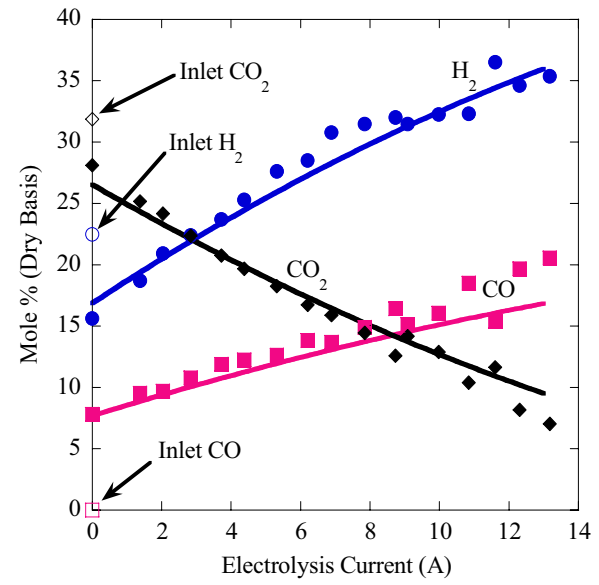

Fig. 9. Test 3 experimental and chemical equilibrium coelectrolysis model results, $T_{e q}=800^{\circ} \mathrm{C}$.

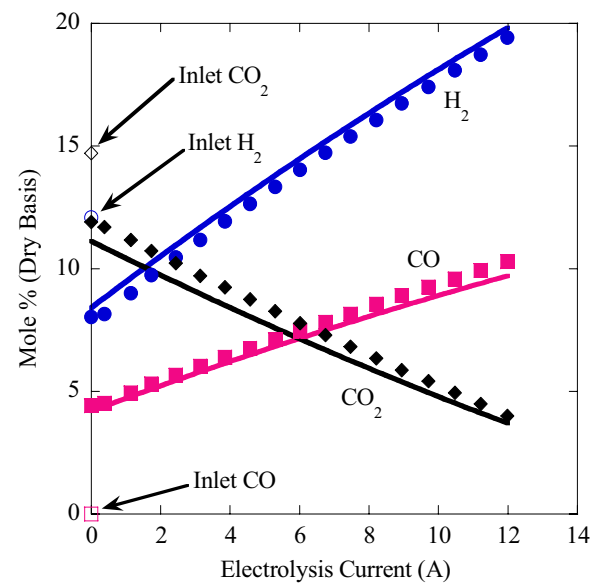

Fig. 11. Test 5 experimental and chemical equilibrium coelectrolysis model results, $T_{e q}=828^{\circ} \mathrm{C}$.

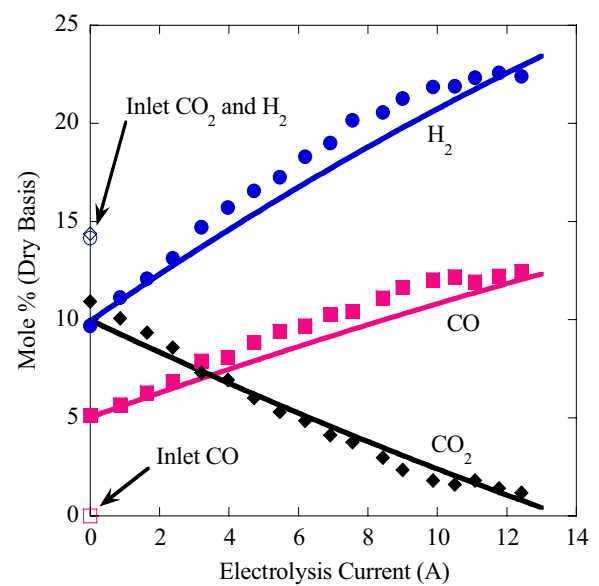

Fig 8. Test 2 experimental and chemical equilibrium coelectrolysis model results, $T_{e q}=800^{\circ} \mathrm{C}$.

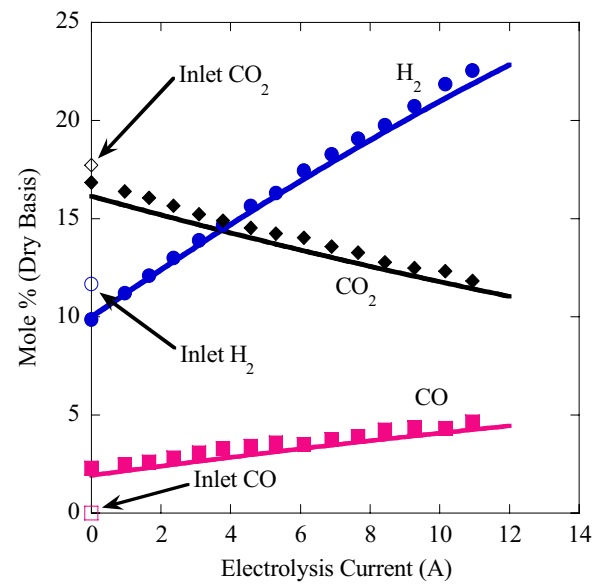

Fig. 10. Test 4 experimental and chemical equilibrium coelectrolysis model results, $T_{e q}=800^{\circ} \mathrm{C}$.

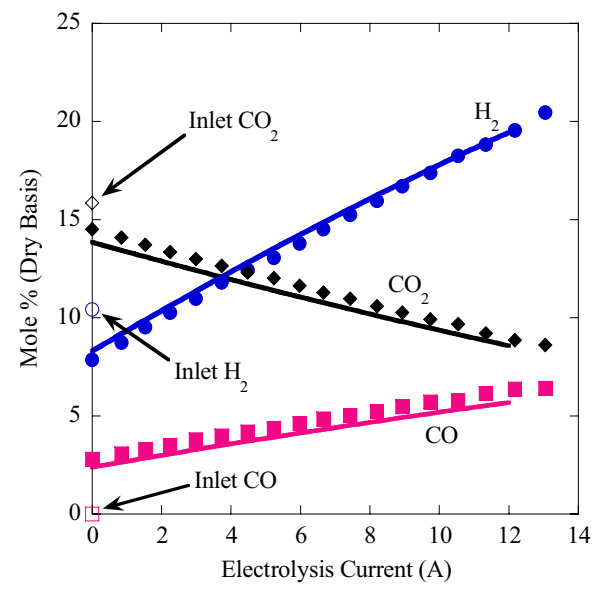

Fig. 12. Test 6 experimental and chemical equilibrium coelectrolysis model results, $T_{e q}=828^{\circ} \mathrm{C}$. 


\section{Methanation Test Results}

Ceramatec Inc. extended their 10-cell stack testing apparatus by addition of a methanation reactor downstream of the stack. The methanation reactor consisted of a $18 \mathrm{~mm}$ inner diameter stainless steel tube, approximately $1.5 \mathrm{~m}$ in length. Within this tube was placed a commercial steam reforming catalyst (R-67R from Haldor Topsoe). This is a nickel catalyst on magnesium aluminate, a ceramic inert oxide of the spinel family. The reactor tube was placed within a zinc-aluminum sleeve to homogenize the axial temperature gradient. The reactor was maintained at approximately $300 \mathrm{C}$ for testing. Testing consisted of high temperature coelectrolysis, with the coelectrolysis products immediately fed to the methanation reactor. Fig. 13 summarizes the stack inlet, stack outlet, and methanation outlet stream compositions (volume \%) for 5 tests. Between 40 and 50 volume \% methane product was produced.

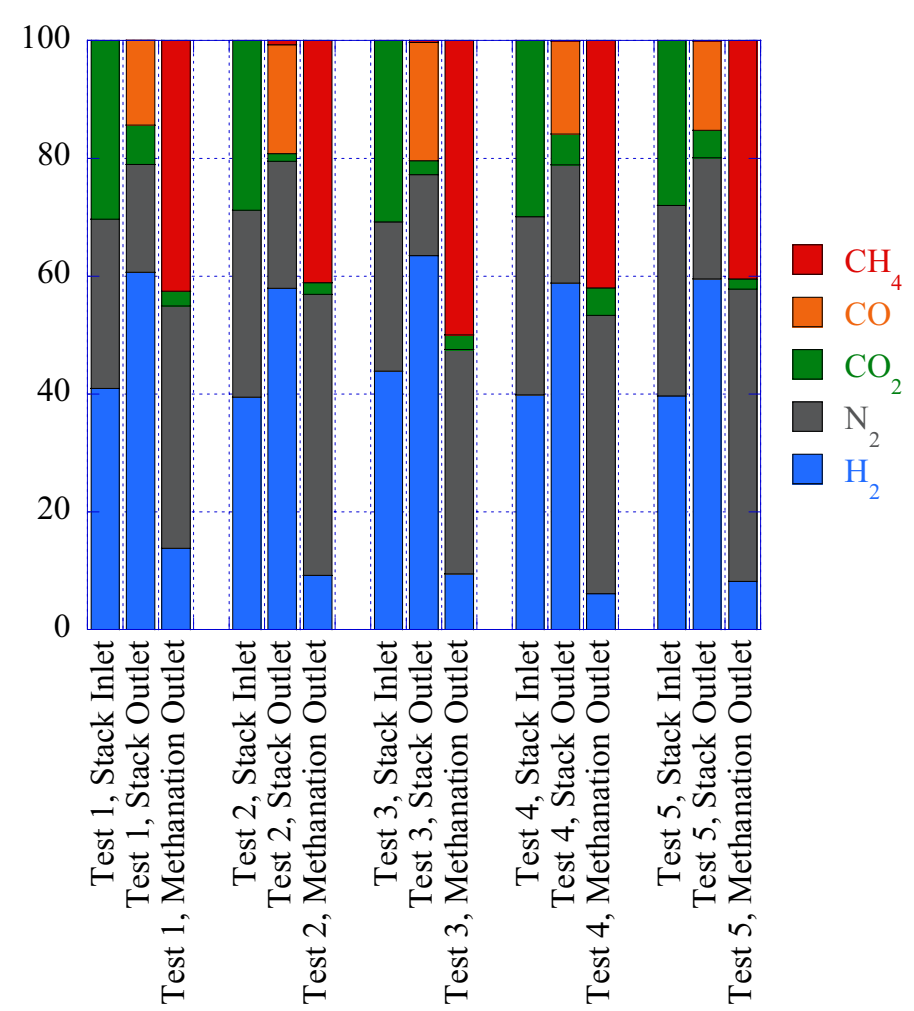

Fig 13. Coelectrolysis with subsequent methanation.

\section{Summary}

Synthetically-derived hydrocarbon fuels can offer an interim solution for domestic energy dependence and a bridge to the hydrogen economy. The raw material for synfuel production is syngas, a mixture of $\mathrm{H}_{2}$ and $\mathrm{CO}$. The Idaho National Laboratory has demonstrated the feasibility of using high temperature solid oxide cells to coelectrolyze $\mathrm{H}_{2} \mathrm{O}$ and $\mathrm{CO}_{2}$ simultaneously to produce syngas. ASRs did not vary substantially between steam electrolysis and steam $/ \mathrm{CO}_{2}$ coelectrolysis, but increased dramatically with $\mathrm{CO}_{2}$ electrolysis. There was overall good agreement between experimental gas chromatograph data for outlet compositions and results from the chemical equilibrium coelectrolysis model. These measurements and model results indicate that coelectrolysis effectively increases the syngas yield for a given steam $/ \mathrm{CO}_{2}$ process stream. The concept of directing coelectrolysis products through a methanation reactor was tested, with yields of $40-50$ volume $\%$ methane being produced. Overall, the coelectrolysis process appears to be a promising technique for large-scale syngas production.

\section{Acknowledgements}

This work was supported by the Idaho National Laboratory, Laboratory Directed Research and Development program and the U.S. Department of Energy, Office of Nuclear Energy, Nuclear Hydrogen Initiative Program. 


\section{References}

1. Stoots, C.M., O'Brien, J.E., Hawkes, G.L., Herring, J.S., Hartvigsen, J.J, “High Temperature Co-Electrolysis of H2O and CO2 for Syngas Production," 2006 Fuel Cell Seminar, Honolulu, Hawaii, Nov. 13-17, 2006, paper no. 418.

2. O’Brien, J.E., Stoots, C.M., Herring, J.S., Hawkes, G.L., Hartvigsen, J.J., "Thermal And Electrochemical Performance Of A High-Temperature Steam Electrolysis Stack," 2006 Fuel Cell Seminar, Honolulu, Hawaii, Nov. 13-17, 2006, paper no. 417.

3. O'Brien, J. E., Stoots, C. M., Herring, J. S., and Hartvigsen, J. J.,"Hydrogen Production Performance of a 10-Cell Planar Solid-Oxide Electrolysis Stack," Journal of Fuel Cell Science and Technology, Vol. 3, pp. 213-219, May, 2006.

4. Stoots, C.M., O'Brien, J.E., Hartvigsen, J.J., "Syngas Production Via High-Temperature Coelectrolysis Of Steam And Carbon Dioxide In A Solid-Oxide Stack," ASME $5^{\text {th }}$

International Fuel Cell Science, Engineering \& Technology Conference, New York, June 1820, 2007, paper no. 25208.

5. Stoots, C.M., O'Brien, J.E., Hartvigsen, J.J., “Test Results Of High Temperature Steam/ $\mathrm{CO}_{2}$ Coelectrolysis In A 10-Cell Stack," American Nuclear Society Embedded Topical Meeting: Safety and Technology of Nuclear Hydrogen Production (ST-NH ${ }_{2}$ ), Boston, June 24-28, 2007. 